\section{The context of observed violence: Inhibition of aggression through displays of unsuccessful retaliation*}

\author{
RUSSELL G. GEEN and DAVID STONNER \\ University of Missouri, Columbia, Mo. 65201
}

Forty male Ss who had previously been angered by a confederate (C) and 40 who had not were shown a boxing movie. The film was described to one-quarter of all Ss as professional aggression, to one-quarter as an unsuccessful attempt at vengeance, and to one-half as a successful attempt at vengeance. Subsequent attacks against $\mathrm{C}$ tended to be most intense in angry Ss who had regarded the movie as revenge and among nonangry $S$ ss who interpreted it as professional violence. The results are attributed to lowering of inhibitions against aggression by the film.

Several investigators have shown that the observation of aggression can be an antecedent of aggressive behavior (e.g., Hartmann, 1969 Walters \& Thomas, 1963). One reason for this aggressive behavior is that a person who witnesses violence may be reminded that aggression is permissible under certain conditions and may thereby lose some socially acquired restraints and inhibitions against acting aggressively. Other studies have shown that restraints against aggression are especially likely to be lowered when the observed violence is interpreted as being justified by the circumstances in which it is enacted. For example, is who have been angered by a confederate and then shown a movie of one man striking another in a prize fight retaliate more intensely when they have been told that the beaten man deserves his beating than when told that he does not (Berkowitz \& Geen, 1967). An experiment by Hoyt (1970) reports even more subtle effects by showing that angry Ss behave more aggressively after being shown a film of a beating described as an instance of revenge than after seeing the same beating described as self-defense.

$A$ recent study by the authors ${ }^{1}$ supports and extends Hoyt's findings. Male Ss were either attacked with electric shocks or treated neutrally by a confederate $(C)$, then shown a boxing movie. Some Ss were told that the film represented successful revenge by the winner for a previous beating, some were told that the two fighters were professionals who held no hatred for each other, and some were told nothing. The intensity with which $S$ later shocked $\mathrm{C}$ was found to be a

* This study was supported by Research Grant GS-2748 from the National Science Foundation to the first author. function of the interaction between the two variables: previously attacked Ss were more aggressive after seeing vengeful aggression on the screen than after seeing professional violence, but nonattacked Ss were more aggressive after seeing the nonhostile professional fighting. Ss also rated the degree to which they had felt restrained in shocking $\mathrm{C}$, and the results paralleled those for shock intensity. Attacked Ss were more restrained after seeing professional aggression than after seeing revenge, but nonattacked Ss expressed greater inhibition after witnessing vengeful violence. The results suggest that the context in which aggression is observed affects a S's restraints against aggression, and hence his aggressive behavior.

The present study replicates and extends the one just described. If a $S$ learns from the ostensible motives of observed aggressors something about the efficacy and propriety of violence, what would be the effect of witnessing an unsuccessful attempt at revenge? If in seeking to avenge himself a person sustains further defeat and misfortune, observers of his plight may become more, rather than less, inhibited about acting aggressively. If the observer is himself motivated by desire for revenge against some enemy of his own, the effect of observing unsuccessful retaliation should be restraint when the person later is able to attack the enemy. The experiment described here replicates two conditions of the earlier study: Ss were shown the boxing film and told that it represented professional aggression or revenge sought by the winning boxer. In a third condition, $S$ was told that revenge was being sought by the man who ultimately loses the fight. In the film, this man is shown lying on the canvas at the end of the scene. In a fourth condition, $S$ was likewise told that the apparent loser of the fight was the one hoping for revenge, and was also told that the man was successful in his quest; this was accomplished by additional instructions which informed $S$ that the conclusion to the film (not shown in the experiment) protrayed this boxer eventually winning the bout. Half the Ss who heard each of the four narratives had previously been attacked by a $C$ and half had not, the result being a 2 by 4 factorial design. SUBJECTS

The Ss were 80 male volunteers recruited from an introductory psychology class. Each $\mathrm{S}$ received 1 point toward his class grade for participating.

\section{PROCEDURE}

The experiment was described as testing the effects of punishment on learning, with $S$ and $C$ in separate booths out of each other's sight. C then gave $\mathrm{S}$ either 2 or 10 electric shocks, supposedly indicative of agreement or disagreement with some opinions stated by $S$; this operationalized the attack/no-attack variable. ${ }^{2} \mathrm{~S}$ and $\mathrm{C}$ were then given a short questionnaire assessing their emotional states; by this means a check was made on how angry $\$$ had been made by the shocks he received. Each $S$ next saw the film, a 6 -min sequence from the movie, "Champion," which depicts a boxer named Dunne administering a savage beating to one named Kelly. Before showing the film, $E$ read to $S$ and $C$ one of four narratives, purportedly to place the scene in a meaningful context. One-fourth of all Ss (vengeance-Dunne condition) were told that the boxer named Dunne had previously been badly beaten by Kelly and was eagerly anticipating the rematch to get even. One-fourth (professional condition) were told that the two men fought only because it was their job and that neither felt any animosity toward the other. One-fourth (vengeance-Kelly fails condition) were told the same narrative as those in the vengeance-Dunne condition, with the names of the boxers reversed. The final fourth (vengeance Kelly) were given the same narrative as $S s$ in the vengeance-Kelly fails condition but were in addition told that Kelly later in the movie recovered his strength and composure and went on to defeat Dunne. In all conditions, the showing of the movie was said to be necessary to provide information to be used later in the experiment by $S$.

At the conclusion of the movie, $S$ was instructed to present to $C$ certain items of information about the film and $C$ was supposedly to form some concepts based on this information. Errors by $C$ were to be punished by S's delivery of electric shock to $C$. The 


\begin{tabular}{lll}
\multicolumn{1}{c}{ Film Context } & \multicolumn{2}{c}{ Treatment } \\
\cline { 2 - 3 } Attack & No Attack \\
\hline Vengeance-Dunne & $6.29_{\mathrm{ab}}$ & $4.72_{\mathrm{c}}$ \\
Vengeance-Kelly & $6.63_{\mathrm{ab}}$ & $4.87_{\mathrm{c}}$ \\
Professional & $5.16_{\mathrm{bc}}$ & $6.82_{\mathrm{a}}$ \\
Vengeance-Kelly Fails & $4.94_{\mathrm{c}}$ & $4.91_{\mathrm{c}}$ \\
\hline
\end{tabular}

Note-All cells having common subscripts are not significantly different at the 05 level by a Duncan multiple-range test.

intensity of shocks used was at S's discretion and could vary across 10 intensities governed by the 10 buttons on a shock box. C made a series of 15 prearranged errors over 20 information trials. After $\mathrm{S}$ had administered shocks to $\mathrm{C}$, both men completed a questionnaire asking them again to rate their emotional states and to give some of their impressions of the film. One item asked $\mathrm{S}$ to rate how much he had "held back," i.e., felt restrained, in shocking $\mathrm{C}$. E then thanked $\mathrm{S}$ for taking part, and interviewed him to ascertain whether the experimental deceptions had succeeded. $S$ was then told the true nature of the study and dismissed.

\section{RESULTS AND DISCUSSION}

Ratings of Anger

Immediately after being shocked by $C$, Ss who received 10 shocks expressed greater anger than those who were given 2 shocks. The mean anger rating of the former (on a continuous $100-\mathrm{mm}$ scale) was 51.6 , and the mean rating of the latter was 34.8 , with the higher score indicating greater anger. This difference is significant $(F=4.42, \mathrm{df}=1,72$, $\mathrm{p}<.05)$. No significant differences as a function of the experimental variables were found for any of the other mood scales given after $C$ shocked S.

\section{Shock Intensity}

The mean intensities of shocks given by $S s$ in the eight conditions are presented in Table 1. An analysis of variance on these data yielded a significant effect only for the Attack by Film Context interaction $(F=3.38$, df $=3,72, p<.05)$. Ss who had been attacked by the confederate and then shown a movie described as a successful attempt at revenge gave significantly stronger shocks in retaliation than did Ss told that the quest for revenge had failed; this was the case regardless of which boxer was the one requiring revenge. The fact that the fighter in the vengeance-Kelly condition sustained a severe beating en route to obtaining satisfaction and appeared at one point to be beaten had no effect on the aggressiveness of the angry observer. Ss in this condition were neither more nor less violent than those who saw Dunne obtain vengeance relatively easily.
Ss who had not been attacked were most aggressive after seeing a fight which they interpreted as nonhostile and professional. Ss in the no-attack-professional condition gave significantly stronger shocks than did nonattacked Ss in any of the other film-context conditions. Nonattacked Ss reacted to the film's portraying successful revenge with as low a level of attack as they did to the one showing a thwarted attempt at vengeance; they apparently responded to the fact of revenge motivation rather than to the efficacy of the behavior it prompted.

Expression of Restraint

The reported restraint felt by Ss as they shocked $\mathrm{C}$ is reported in Table 2 , with a high scale score representing a low degree of felt restraint. The interaction between the two variables is significant $(\mathrm{F}=5.50$, $\mathrm{df}=3,72$, p $<.01$ ). Attacked Ss expressed lower restraints against aggressing after seeing successful revenge by Dunne than did attacked Ss in any of the other four conditions. Surprisingly, Ss in the vengeance-Kelly condition were as inhibited in aggressing as those in the vengeance-Kelly fails condition, even though they were more aggressive. With this exception, the data on restraint for attacked Ss parallels that for aggression and suggests that the context in which the film was placed affected both variables. Ss who had been angered by an attack were possibly disinhibited by seeing successful vengeance by Dunne which did not cost Dunne very much, since he was not badly beaten in the process. Probably $S s$ in the vengeance-Kelly condition were not disinhibited because they learned that revenge, while being attainable, might nevertheless be expensive in terms of the suffering one must endure to achieve it.

Ss who had not been attacked tended to be most disinhibited by the professional film context, although their restraints were significantly lower than those of $S s$ in the vengeance-Dunne condition only, Nevertheless, the pattern of results for nonattacked Ss-high aggression and low restraints after witnessing professional violence but low aggression and high restraints after vengeful aggression-is quite similar to that found by the authors in the previous experiment.

The finding that observation of professional aggression produced greater lessening of restraints and more aggressiveness in nonattacked Ss replicates the similar finding from the previous study. Perhaps, as the authors reasoned there, the nonattacked person, since he is not angry at $C$, is motivated to aggress only by a desire to comply with E's instructions. In other words, he aggresses not out of hostility, but because aggression is instrumental to the attainment of another goal: E's approval. He experiences a greater reduction in inhibitions against aggression by the example of another person (the winning boxer) aggressing for nonhostile reasons than he would had he observed someone attacking out of a desire for revenge. The propriety of one's own aggression may be determined by comparing one's motives with those of the aggressor on the screen.

Two other ratings were made by $S$ s in the experiment's final questionnaire and both are relevant to our discussion. One was S's rating of how violent he judged the film to be; the results of these ratings revealed no significant main effects for the two independent variables and no interaction. We may, therefore, rule out the possibility that the differences in shock intensity were due to the investing of the film with different levels of "violent content" by the introductory narratives. Ss in each of the eight conditions tended to regard the film as equally violent. Our context narratives therefore did not

Table 2

Mean Degree of Restraint Against Shocking Reported by Ss

\begin{tabular}{lll}
\multicolumn{1}{c}{ Film Context } & \multicolumn{2}{c}{ Treatment } \\
\cline { 2 - 3 } & Attack & No Attack \\
\hline Vengeance-Dunne & $64.40_{\mathrm{a}}$ & $27.61_{\mathrm{c}}$ \\
Vengeance-Kelly & $35.80_{\mathrm{bc}}$ & $39.31_{\mathrm{bc}}$ \\
Professional & $35.80_{\mathrm{bc}}$ & $49.60_{\mathrm{ab}}$ \\
Vengeance-Kelly Fails & $29.76_{\mathrm{bc}}$ & $31.20_{\mathrm{bc}}$ \\
\hline
\end{tabular}

Note-The higher the scale score. the lower the degree of reported restraint. Cells having common subscripls are not significantly different at the 05 level by a Duncan multiple range test. 
give the film different cue values for eliciting aggressive responses (Berkowitz, 1965). The second rating involved S's description of how generally excited and emotional he had felt while watching the film. These ratings likewise failed to reveal variance across experimental conditions, allowing us to rule out differences in emotional arousal as a result of film contexts as an explanation for the differences in aggression. The conclusion best warranted by the data is that the interpretations which an observer places on witnessed violence affect the restraints he feels over aggressing. If he experiences a reduction in restraints through his interpretations and is also motivated to aggress for some reason, he will be more likely to behave aggressively than he would have had he interpreted the witnessed violence in a different, more inhibiting way.

\section{REFERENCES}

BERKOWIT2 L. The concept of aggressive drive: Some additional considerations. In L. Berkowit 2 (Ed.). Advances in experimental social psychology. Vol. 2 New York: Academic Press, 1965

BERKOWITZ, I.. \& GEEN, R. G. Stimulus qualities of the target of aggression: A further study. Journal of Personality \& Social Psy chology, 1967, 5, 364-368.

GEEN, R. G. Perceived suffering of the victirn as an iahibitor of attack-induced aggression. Journal of Social Psychology. 1970,81, 209-215.

HARTMANN D. P. Influence of symbolically modeled instrumental aggression and pain cues on aggressive behavior. Journal of Personality \& Social Psychology, 1969, 11, 280-288.

HOYT. J. L. Effect of media violence "justification" on aggression. Joumal of Broadcasting. 1970, 16, 455-464.

WALTERS. R. H, \& THOMAS, E. L. Enhancement of punitiveness by visual and a udiovisual displays. Canadian Journal of Psychology, 1963, 17 244-255

\section{NOTES}

1. Geen, R. G., \& Stonner. D. Context effects in observed violence. Unpublished manuscript, University of Missouri, 1971.

2 . Complete details of the procedure are given by Geen (1970) 